\title{
Development and Productivity of Jatropha curcas Plants Treated With Growth Regulators
}

\author{
V. A. Amorim ${ }^{1}$, C. L. Amaro ${ }^{1}$, L. V. Rossato ${ }^{1}$, I. A. S. Freitas ${ }^{1}$, K. G. Simão ${ }^{1}$, G. H. F. de Lima ${ }^{1}$, \\ G. S. Parreira ${ }^{1}$, L. P. Borges ${ }^{1}$, J. P. P. Gardin ${ }^{2} \&$ F. S. Matos ${ }^{1}$ \\ ${ }^{1}$ Research Group on Physiology of Vegetable Production, State University of Goiás, Ipameri, Brazil \\ ${ }^{2}$ Company of Agricultural Research and Rural Extension of Santa Catarina, Epagri, Brazil \\ Correspondence: F. S. Matos, State University of Goiás, Highway GO 330 km 241, Ring Road, Zip Code \\ 75780-000, Ipameri, Brazil. E-mail: fabio.agronomia@hotmail.com
}

Received: January 22, 2019

Accepted: February 28, 2019

Online Published: April 15, 2019

doi:10.5539/jas.v11n5p302

URL: https://doi.org/10.5539/jas.v11n5p302

\begin{abstract}
The objective of the present work was to evaluate the effect of plant growth regulators (PGR) on the vegetative development and productivity of Jatropha curcas plants. A field experiment was conducted at the Goiás State University, Brazil, using two-year-old $J$. curcas plants planted with spacing of $3 \times 2 \mathrm{~m}$, using foliar applications of two PGR - trinexapac-ethyl and prohexadione-Ca. A randomized block design was used with four treatments (trinexapac-ethyl at $1 \mathrm{ml}$ plant ${ }^{-1}-\mathrm{T} 1$; prohexadione-Ca at $2 \mathrm{mg}$ plant $^{-1}-\mathrm{T} 2$; trinexapac-ethyl at $1 \mathrm{ml}^{\text {plant }}{ }^{-1}$ plus prohexadione-Ca at $2 \mathrm{mg}$ plant $^{-1}-\mathrm{T} 3$; and Control- $-\mathrm{T} 4$ ), five replications, and plots consisting of two plants. Two applications of a $300 \mathrm{ml} \mathrm{plant}^{-1}$ solution with the treatments were performed with a 30-day interval after the leaf emergence period (late September and October 2017). The trinexapac-ethyl and prohexadione-Ca plant growth regulators increased the grain yield of Jatropha curcas plants by increasing their vegetative growth, and number of inflorescences, and female and hermaphrodite flowers, but had no effect on the uniformity of fruit maturation. The treatment in which both plant growth regulators were used presented the best results, generating more vigorous and productive plants.
\end{abstract}

Keywords: biofuel, ecophysiology, phytohormones

\section{Introduction}

Greenhouse gas emissions resulted from human actions affect negatively natural resources and increase the need for renewable energy sources that reduce environmental impacts (Schrag, 2018). Biofuel markets have sought to produce clean and renewable fuels due to the need for reducing the dependence on fossil fuels, focusing on a sustainable development (Gaurav, Sivasankari, Kiran, Ninawe, \& Selvin, 2017).

The researches that have been developed and the political actions created by the National Program for the Production and Use of Biodiesel (PNPB) in Brazil have promoted the production of biofuels to increasingly replace petroleum diesel through the gradually mixing of it with biodiesel (Nogueira \& Capaz, 2017). This program (PNPB) increased biodiesel production to more than 4 million $\mathrm{m}^{-3}$ in 2017, surpassing all previous years (ANP, 2018).

The main raw materials used to produce biodiesel in Brazil are soybean $(68.60 \%)$, bovine fat $(12.81 \%)$, and cotton $(2.13 \%)$; other oil materials represent $11.60 \%$ and other raw materials $4.85 \%$ of this production (ANP, 2018). Therefore, diversifying the raw materials for biodiesel production is needed; it can be accomplished by the introduction of promising species such as Jatropha curcas L. (Moniruzzaman, Yaakob, Shahinuzzaman, Khatun, \& Islam, 2017).

$J$. curcas (Euphorbiaceae) has multiple applications, from biodiesel production to cosmetics industries (Moniruzzaman et al., 2017). J. curcas is also used to produce biopesticides and drugs, since its latex has antimicrobial, anti-cancerous, and anti-inflammatory properties (Raulf, 2014; Matos, Ciappina, Rocha, \& Almeida, 2018). However, this species has drawn worldwide attention as an alternative source of sustainable energy, mainly due to the high oil content of its seeds. It reaches productive climax after four years in the field, producing 4 to $5 \mathrm{~kg}$ of seeds per year when grown under suitable conditions, and has a production period of 30 to 50 years (Banapurmath, Tewari, \& Hosmath, 2008). However, this species is in process of domestication and 
lacks scientific evaluations that ensure high yields (Montes \& Melchinger, 2016). In addition, the low yield and lack of fruit maturity uniformity limit the competitiveness of this crop species (Lama, Klemola, Saloniemi, Niemelä, \& Vuorisalo, 2018).

The harvest of $J$. curcas fruits can last four to six months. Emergence of new inflorescences is commonly found in the first months of fruit harvesting; thus, the same plant has mature fruits, open flowers, and emergence of inflorescences. Therefore, fruit harvesting is laborious and expensive, significantly reducing profitability, making this crop practically impossible in certain regions (Heinrich, 2018).

The different flower emergence times of $J$. curcas plants may be due to the competition for assimilates between vegetative and reproductive organs, and indicate the need of management practices to control vegetative growth (Grosh et al., 2010). Thus, researches describing aspects of fruit maturation and practices that promote uniformization of harvest and increase profitability by lowering labor costs are necessary.

The low numbers of branches and female flowers limit yield of $J$. curcas plants, thus, increasing these numbers is advantageous for commercial crops of this species (Oliveira et al., 2012). The use of plant growth regulators (PGR) is an important practice that changes the proportion of female and male flowers and reduces competition for assimilates between vegetative and reproductive components (Pan \& Xu, 2011).

PGR are widely used in several crops to stimulate productive response and control plant growth. Several PGR have been tested in $J$. curcas for floral development and grain production (Gouveia et al., 2012; Seesangboon et al., 2018; Hui, Wang, Chen, Zayed, \& Wu, 2018), however, the use of techniques aiming at obtaining uniformity of fruit maturity by the use of regulators is absent in the literature and, in this sense, the present study becomes unprecedented when prioritizing the synchronization of fruit maturation of $J$. curcas. In this context, the objective of the present work was to evaluate the effect of PGR on the vegetative development and productivity of $J$. curcas plants.

\section{Material and Methods}

The study was developed in the experimental area of the Goiás State University, in Ipameri, state of Goiás, Brazil $\left(17^{\circ} 43^{\prime} 19^{\prime \prime} \mathrm{S}, 48^{\circ} 09^{\prime} 35^{\prime \prime} \mathrm{W}\right.$, and altitude of $\left.773 \mathrm{~m}\right)$. The region has a tropical humid climate (rainy summers and dry winters), with well-defined rainy (October to March) and dry (April to September) seasons. The soil of the experimental area was classified as Red-Yellow Latosol (Oxisol) (Dos Santos et al., 2013). Liming and fertilization were performed based on soil analysis, following technical recommendations for the crop (Matos et al., 2014).

A field experiment was conducted using two-year-old $J$. curcas plants planted with spacing of $3 \times 2$, using foliar applications of two plant growth regulators (PGR) that inhibit gibberellin synthesis trinexapac-ethyl (Moddus ${ }^{\circledR}$, Syngenta, Basel, Switzerland) and prohexadione-Ca (Viviful, Iharabras, Sorocaba, Brazil). A randomized block design was used with four treatments (trinexapac-ethyl at $1 \mathrm{ml} \mathrm{plant}^{-1}-\mathrm{T} 1$; prohexadione-Ca at $2 \mathrm{mg}$ plant $^{-1}-\mathrm{T} 2$; trinexapac-ethyl at $1 \mathrm{ml} \mathrm{plant}^{-1}$ plus prohexadione-Ca at $2 \mathrm{mg}$ plant $^{-1}-\mathrm{T} 3$; and Control-T4), five replications, and plots consisting of two plants.

Two applications of a $300 \mathrm{ml} \mathrm{plant}^{-1}$ solution with the treatments were performed with a 30-day interval after the leaf emergence following the plant's deciduous period, from late September to October 2017. The treatments were applied as uniform as possible by spraying the solution on the leaf area of the plants, reaching the whole canopy, and avoiding overflow.

Plant height, crown diameter, number of branches, leaf chlorophyll and carotenoid contents, and stomatal density were evaluated at 15 days after the last application. Number of female and hermaphrodite flowers per plant, number of inflorescences per plant, and grain yield were evaluated at 60,90 and 120 days after the last application.

Plant height was measured from the stem base to apex using a tape ruler. Crown diameter was measured in the East-West direction of the crown using a tape ruler. Chlorophyll and carotenoid contents were determined in two $0.6 \mathrm{~mm}$ diameter disks from fully developed leaves placed into glasses containing dimethyl sulfoxide (DMSO). The extraction was carried out in a water bath at $65^{\circ} \mathrm{C}$ for one hour; aliquots were spectrophotometrically read at 480,646 , and $663 \mathrm{~nm}$; and chlorophyll- $a$, chlorophyll- $b$, and carotenoids contents were determined following the equation proposed by Wellburn (1994).

Samples were taken from the adaxial and abaxial surfaces of middle third of previously dehydrated fully developed leaves, following recommendations of Oliveira et al. (2016) for stomatal count, which was performed using an optical microscope equipped with a light chamber. The stomatal density was defined as the number of 
stomata in $1 \mathrm{~mm}^{2}$ of both leaf surfaces. The number of inflorescences and number of female and hermaphrodite flowers were defined by counting, with visual differentiation of them.

Fruits were manually harvested when presenting dark brown skin color; they were peeled, left to dry to reach a $13 \%$ moisture, and weighed. Grain production per plant was determined by weighing the total grains obtained per plant.

Data were subjected to analysis of variance and to Newman-Keuls test for comparison of means. Principal component analysis was performed using a correlation matrix and the Forward Stepwise model selection criterion (Sokal \& Rolf, 1995). A permutational multivariate analysis of variance was used (Anderson, 2001). The software R (R Core Team, 2018) was used to perform these analyses.

\section{Results and Discussion}

The analysis of variance for plant height, number of branches, crown diameter, stomatal density, and grain yield of $J$. curcas plants subjected to the different plant growth regulators (PGR) used is shown in Table 1 . The $J$. curcas plants showed significant differences in growth and yield depending on the treatments. Plants treated with PGR had higher plant height, number of branches, crown diameter, stomatal density, and yield than control plants. T2 plants had higher plant height (6\%), number of branches $(29 \%)$, and crown diameter (19\%) than control plants; and T3 plants had higher stomatal density (30\%) and yield (29\%) than control plants.

Table 1. Summary of variance analysis and mean test of plants of $J$. curcas submitted to different growth regulators TrixE (T1), ProCa (T2), TrixE + ProCa (T3) and control (T4)

\begin{tabular}{|c|c|c|c|c|c|c|}
\hline \multirow{2}{*}{ Variation source } & \multirow{2}{*}{ DF } & \multicolumn{5}{|c|}{ Mean squares } \\
\hline & & $\mathrm{PH}(\mathrm{m})$ & NB & $\mathrm{CD}(\mathrm{m})$ & $\mathrm{SD}\left(\mathrm{mm}^{2}\right)$ & $\operatorname{PROD}\left(\mathrm{kg} \mathrm{ha}^{-1}\right)$ \\
\hline Treatments & 3 & $0.3099 * *$ & $492.933 * *$ & $0.198 * *$ & $143.12 * *$ & $126572.07 * *$ \\
\hline Blocks & 4 & $0.0247^{\mathrm{ns}}$ & $14.325^{\mathrm{ns}}$ & $0.0084^{\mathrm{ns}}$ & $12.825^{\mathrm{ns}}$ & $5987.07^{\mathrm{ns}}$ \\
\hline Error & 12 & 0.1687 & 29.725 & 0.0092 & 17.325 & 12411.27 \\
\hline $\mathrm{CV} \%$ & & 4.24 & 7.83 & 4.05 & 13.15 & 9.98 \\
\hline Treatments & & \multicolumn{5}{|c|}{ Means } \\
\hline $\mathrm{T} 1$ & & $2.45 \mathrm{c}$ & $68.8 \mathrm{~b}$ & $2.33 b$ & $28.4 b$ & $1160.8 \mathrm{ab}$ \\
\hline $\mathrm{T} 2$ & & $3.06 \mathrm{a}$ & $78.6 \mathrm{a}$ & $2.61 \mathrm{a}$ & $31.0 \mathrm{~b}$ & $1069.2 \mathrm{bc}$ \\
\hline $\mathrm{T} 3$ & & $2.79 b$ & $75.0 \mathrm{ab}$ & $2.43 b$ & $39.4 \mathrm{a}$ & $1306.2 \mathrm{a}$ \\
\hline $\mathrm{T} 4$ & & $2.88 \mathrm{~b}$ & $56.0 \mathrm{c}$ & $2.13 c$ & $27.8 \mathrm{~b}$ & $927.4 \mathrm{c}$ \\
\hline
\end{tabular}

Note. $\mathrm{PH}=$ plant height; $\mathrm{NB}=$ number of branches; $\mathrm{CD}=$ crown diameter; $\mathrm{SD}=$ stomatal density; $\mathrm{PROD}=$ productivity. *significant at $5 \%$ and at $* * 1 \%$ probability; ns $=$ not significant according to the $\mathrm{F}$ test. Means followed by the same lower case letter in the column do not differ at $5 \%$ probability according to the Newman-Keuls test.

PGR affect plant height by inhibiting gibberellin synthesis. According to Looney (2018), PGR generally paralyze plant growth and modify the partition of photoassimilates by directing the surplus of assimilates to drains. However, in the present study, the vegetative growth was not paralyzed by the PGR used; the number of branches and crown diameter of the $J$. curcas plants increased with the application of PGR, therefore, there was no inhibition of gibberellin synthesis and consequent reduction of plant size.

Plants treated with trinexapac-ethyl + prohexadione-Ca (T3) presented the highest yields. The increase in number of branches, crown diameter, and stomatal density probably contributed to the increased yield of T3 plants when compared to the control plants. However, the higher yield of T3 plants in relation to T2 and T1 plants is probably related to their high number of stomata, which results in a greater carboxylation capacity and assimilate production. According to Caine et al. (2018), a high stomatal density results in a greater capacity of the plants in absorb atmospheric $\mathrm{CO}_{2}$ and, therefore, increases photosynthetic efficiency.

According to the analysis of variance and mean test (Table 2), no significant variation for photosynthetic pigments (chlorophylls and carotenoids) as a function of PGR treatments was found. However, plants treated with PGR had higher number of inflorescences, and hermaphrodite and female flowers than control plants, with T3 plants presenting $26 \%$ higher number of inflorescences, $25 \%$ higher number of hermaphrodite flowers, and $24 \%$ higher number of female flowers than control plants. 
Table 2. Summary of variance analysis and mean test from plants of $J$. curcas submitted to different growth regulators TrixE (T1), ProCa (T2), TrixE + ProCa (T3) and control (T4)

\begin{tabular}{|c|c|c|c|c|c|c|c|}
\hline \multirow{2}{*}{ Variation source } & \multirow{2}{*}{ DF } & \multicolumn{6}{|c|}{ Mean squares } \\
\hline & & Chl $a\left(\mathrm{~g} \mathrm{~kg}^{-1}\right)$ & $\mathrm{Chl} b\left(\mathrm{~g} \mathrm{~kg}^{-1}\right)$ & Car $\left(\mathrm{g} \mathrm{kg}^{-1}\right)$ & NIF & NHF & NFF \\
\hline Treatments & 3 & $5.16^{\mathrm{ns}}$ & $0.7^{\mathrm{ns}}$ & $0.022^{\mathrm{ns}}$ & $335.26^{* *}$ & $129.1^{* *}$ & $1959.2 * *$ \\
\hline Blocks & 4 & $6.00^{\mathrm{ns}}$ & $0.41^{\mathrm{ns}}$ & $0.690^{\mathrm{ns}}$ & $58.42^{\mathrm{ns}}$ & $32.5^{\mathrm{ns}}$ & $334.12^{\mathrm{ns}}$ \\
\hline Error & 12 & 6.66 & 0.55 & 0.459 & 21.39 & 13.2 & 120.89 \\
\hline $\mathrm{CV} \%$ & & 10.20 & 12.04 & 10.59 & 6.87 & 8.81 & 6.85 \\
\hline Treatments & & \multicolumn{6}{|c|}{ Means } \\
\hline $\mathrm{T} 1$ & & $3.0 \mathrm{a}$ & $0.9 \mathrm{a}$ & $0.8 \mathrm{a}$ & $68.6 \mathrm{a}$ & $40.6 \mathrm{a}$ & $165.8 \mathrm{a}$ \\
\hline $\mathrm{T} 2$ & & $2.8 \mathrm{a}$ & $1.0 \mathrm{a}$ & $0.7 \mathrm{a}$ & $69.0 \mathrm{a}$ & $44.0 \mathrm{a}$ & $171.8 \mathrm{a}$ \\
\hline $\mathrm{T} 3$ & & $3.0 \mathrm{a}$ & $0.8 \mathrm{a}$ & $0.8 \mathrm{a}$ & $75.6 \mathrm{a}$ & $46.0 \mathrm{a}$ & $173.2 \mathrm{a}$ \\
\hline $\mathrm{T} 4$ & & $2.8 \mathrm{a}$ & $0.8 \mathrm{a}$ & $0.7 \mathrm{a}$ & $56.0 \mathrm{~b}$ & $34.4 b$ & $131.1 \mathrm{~b}$ \\
\hline
\end{tabular}

Note. Chl $a=$ foliar concentrations of chlorophyll $a$; Chl $b=$ foliar concentrations of chlorophyll $b$ Car $=$ total carotenoids; NIF = number of inflorescences; NHF = hermaphrodite flowers; NFF = female flowers. *significant at $5 \%$ and at $* * 1 \%$ probability; ns $=$ not significant according to the $\mathrm{F}$ test. Means followed by the same lower case letter in the column do not differ at $5 \%$ probability according to the Newman-Keuls test.

The grain yield of the $J$. curcas plants is related to the number of branches and number of inflorescences (Matos et al., 2014). Thus, the higher the number of branches the higher the number of inflorescences and, consequently, the higher the number of fruits. According to Oliveira et al. (2016), the reproductive structures of J. curcas are at the apical end of the branches, and the number of fruits of the plant is directly connected to the number of branches, however, not all branches have inflorescences. Therefore, despite the positive correlation between number of branches and fruit production, it is common that some branches produce no fruit.

The application of trinexapac-ethyl + prohexadione-Ca (T3) increased the number of branches and inflorescences; and the high number of hermaphrodite flowers and female flowers contributed to increase fruit yield. According to Rao, Korwar, Shanker, and Ramakrishna, (2008) inflorescences have about 100-300 flowers with an average production of 10 fruits due to the low number of female flowers and hermaphrodite flowers.

The principal component analysis represents $72.1 \%$ of the data variation (Figure 1) and significantly formed two groups; the first composed of control plants without PGR applications, and the second to the right of the axis 1, represented by all PGR treatments. The number of branches was determinant for the ordering of the groups, and denoted the effect of the PGR in breaking bud dormancy and increasing the number of branches and inflorescences and, consequently, grain yield.

The low yield of $J$. curcas plants reported in some studies (Matos et al., 2012; Govender et al., 2018; Lama et al., 2018) was not found in the present study. Plants treated with trinexapac-ethyl + prohexadione-Ca (T3) produced, on average, $1.306 \mathrm{~kg}$ per plant, and control plants produced $0.927 \mathrm{~kg}$ per plant. According to Behera, Srivastava, Tripathi, J. P. Singh, and N. Singh (2010), J. curcas plantations are economically profitable when the fruit yields of plants older than four years are at least $2 \mathrm{~kg} \mathrm{plant}^{-1}$ year ${ }^{-1}$. 


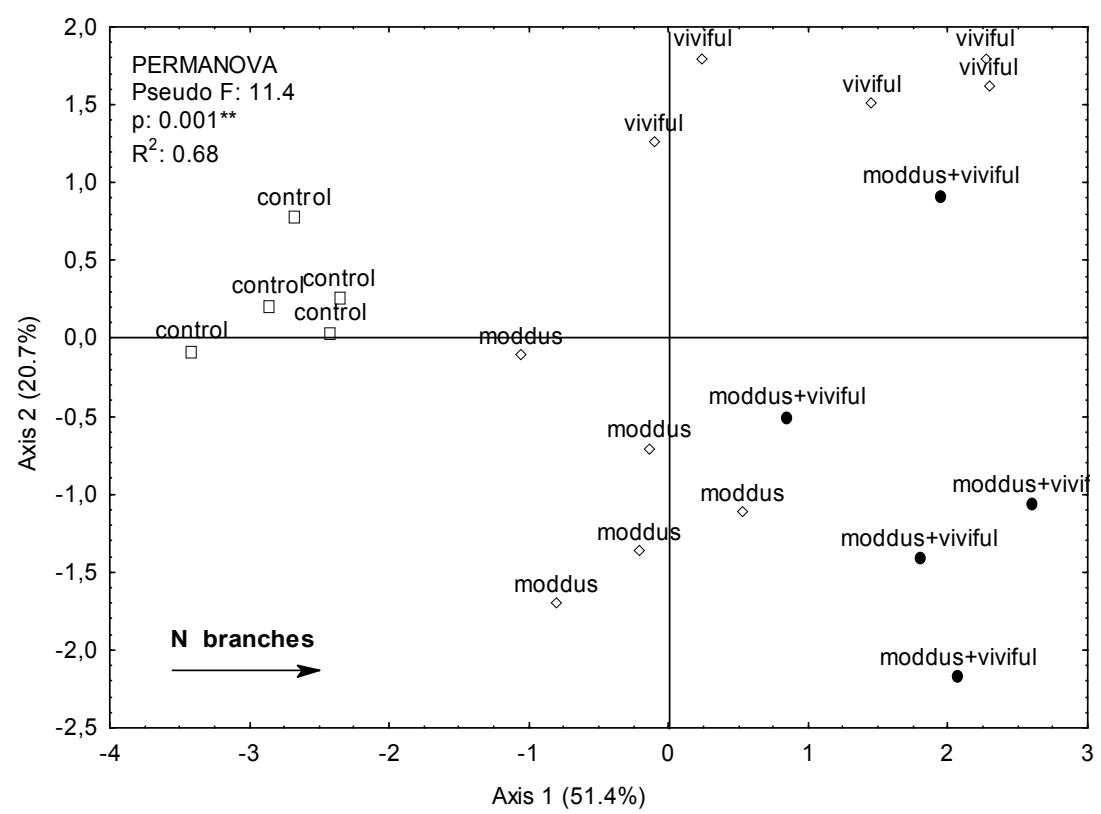

Figure 1. Principal Component Analysis of $J$. curcas plants under different growth regulators TrixE (Moddus ${ }^{\circledR}$ ), prohexadione-Ca (Viviful), prohexadione-Ca + TrixE and control

The plants used in the present study had two years of age and, therefore, they were at the initial stage of growth. The results denote the greater vegetative development and increased grain yield of $J$. curcas plants subjected to PGR. The use of PGR may become an innovative and routinely practice for $J$. curcas plantations after further testing to define the concentration to be used, however, it should be noted that PGR had no effect on fruit ripeness uniformity of $J$. curcas.

\section{Conclusions}

The trinexapac-ethyl and prohexadione-Ca plant growth regulators increased the grain yield of Jatropha curcas plants by increasing their vegetative growth, and number of inflorescences, and female and hermaphrodite flowers, but had no effect on the uniformity of fruit maturation. The treatment in which both plant growth regulators were used presented the best results, generating more vigorous and productive plants.

\section{References}

ANP (Agência Nacional do Petróleo, Gás Natural e Biocombustíveis). (2018). Retrieved from http://www.anp. gov.br/...BIOCOMBUSTIVEIS/.../Processamento_de_materias-primas.xlsx

Anderson, M. J. (2001). A new method for non-parametric multivariate analysis of variance. Austral Ecology, 26, 32-46. https://doi.org/10.1111/j.1442-9993.2001.01070.pp.x

Banapurmath, N. R., Tewari, P. G., \& Hosmath, R. S. (2008). Performance and emission characteristics of a DI compression ignition engine operated on Honge, Jatropha and sesame oil methyl esters. Renewable Energy, 33(9), 1982-1988. https://doi.org/10.1016/j.renene.2007.11.012

Behera, S. K., Srivastava, P., Tripathi, R., Singh, J. P., \& Singh, N. (2010). Evaluation of plant performance of Jatropha curcas L. under different agro-practices for optimizing biomass-A case study. Biomass \& Bioenergy, 34(1), 30-41. https://doi.org/10.1016/j.biombioe.2009.09.008

Caine, R. S., Yin, X., Sloan, J., Harrison, E. L., Mohammed, U., Fulton, T., ... Gray, J. E. (2018). Rice with reduced stomatal density conserves water and has improved drought tolerance under future climate conditions. New Phytologist, 221(1), 371-384. https://doi.org/10.1111/nph.15344

Santos, H. G. dos, Jacomine, P. K. T., Anjos, L. H. C. dos, Oliveira, V. A. de, Lumbreras, J. F., Coelho, M. R., ... Oliveira, J. B. de. (2013). Sistema brasileiro de classificação de solos (3rd ed., p. 353). Brasília, DF: Embrapa.

Gaurav, N., Sivasankari, S., Kiran, G. S., Ninawe, A., \& Selvin, J. (2017). Utilization of bioresources for sustainable biofuels: A review. Renewable and Sustainable Energy Reviews, 73, 205-214. https://doi.org/ 10.1016/j.rser.2017.01.070 
Ghosh, A., Chikara, J., Chaudhary, D. R., Aruna, R., Prakash, G., \& Zala, B. A. (2010). Paclobutrazol arrests vegetative growth and unveils unexpressed yield potential of Jatropha curcas. Journal of Plant Growth Regulation, 29(3), 307-315. https://doi.org/10.1007/s00344-010-9137-0

Gouveia, E. J., Rocha, R. B., Laviola, B. G., Ramalho, A. R., Ferreira, M. G. R., \& Dias, L. A. S. (2012). Aumento da produção de grãos de pinhão-manso pela aplicação de benziladenina. Pesquisa Agropecuária Brasileira, 47(10), 1541-1545. https://doi.org/10.1590/S0100-204X2012001000018

Govender, N., Senan, S., Sage, E. E., Mohamed-Hussein, Z-A., Mackeen, M. M., \& Wickneswari, R. (2018). An integration of phenotypic and transcriptomic data analysis reveals yield-related hub genes in Jatropha curcas inflorescence. PloS One, 13(9), 1-23. https://doi.org/10.1371/journal.pone.0203441

Heinrich, G. (2018). Jatropha curcas L.-An Alternative Oil Crop. In M. Kaltschmitt, \& U. Neuling (Eds.), Biokerosene (pp. 237-257). Springer, Berlin, Heidelberg. https://doi.org/10.1007/978-3-66253065-8_11

Hui, W. K., Wang, Y., Chen, X. Y., Zayed, M. Z., \& Wu, G. J. (2018). Analysis of Transcriptional Responses of the Inflorescence Meristems in Jatropha curcas Following Gibberellin Treatment. International Journal of Molecular Sciences, 19(2), 2-18. https://doi.org/10.3390/ijms 19020432

Lama, A. D., Klemola, T., Saloniemi, I., Niemelä, P., \& Vuorisalo, T. (2018). Factors affecting genetic and seed yield variability of Jatropha curcas (L.) across the globe: A review. Energy for Sustainable Development, 42, 170-182. https://doi.org/10.1016/j.esd.2017.09.002

Looney, N. E. (2018). Growth regulator usage in apple and pear production. Plant growth regulating chemicals (pp. 1-26). CRC Press. https://doi.org/10.1201/9781351075756-1

Matos, F. S., Ciappina, A. L., Rocha, E. C., \& Almeida, L. M. (2018). Factors that influence in Jatropha curcas L. latex production. Bragantia, 77(1), 74-82. https://doi.org/10.1590/1678-4499.2016468

Matos, F. S., Rosa, V. R., Borges, L. F. O., Ribeiro, R. P., Cruvinel, C. K. L., \& Dias, L. A. S. (2014). Response of Jatropha curcas Plants to Changes in the Availability of Nitrogen and Phosphorus in Oxissol. Academic Jounals, 9(49), 3581-3586. https://doi.org/10.5897/AJAR2014.9188

Matos, F. S., Oliveria, L. R., Freitas, R. G., Evaristo, A. B., Missio, R. F., \& Cano, M. A. O. (2012). Physiological characterization of leaf senescence of Jatropha curcas L. populations. Biomass and Bioenergy, 45, 57-64. https://doi.org/10.1016/j.biombioe.2012.05.012

Moniruzzaman, M., Yaakob, Z., Shahinuzzaman, M., Khatun, R., \& Islam, A. A. (2017). Jatropha Biofuel Industry: The Challenges. Frontiers in Bioenergy and Biofuels, 1(12), 223-256. https://doi.org/10.5772/ 64979

Montes, J. M., \& Melchinger, A. E. (2016). Domestication and Breeding of Jatropha curcas L. Trends in Plant Science, 21(12), 1045-1057. https://doi.org/10.1016/j.tplants.2016.08.008

Nogueira, L. A. H., \& Capaz, R. S. (2017). Incentives and barriers for liquid biofuels in Brazil. Handbook of Bioenergy Economics and Policy, 2, 65-88. https://doi.org/10.1007/978-1-4939-6906-7_4

Oliveira, J. P. M., Silva, J. F., Oliveira, B. S., Santos, P. G. F., Silveira, P. S., \& Matos, F. S. (2016). Phenotypic characterization of physic nut populations. African Journal of Agricultural Research, 11(45), 4559-4566. https://doi.org/10.5897/AJAR2016.11647

Oliveira, R. J. P. de, Donini, L. P., Ferreira Neto, D. T., Mayer, K. C. de A., Silva, M. T. da, \& Silva, S. D. dos A. (2012). Influência de reguladores de crescimento na floração feminina e na frutificação de pinhão manso (Jatropha curcas L.). Simpósio Estadual de Agroenergia IV Reunião técnica de agroenergia-RS. Retrieved from https://ainfo.cnptia.embrapa.br/digital/bitstream/item/75474/1/083.pdf

Pan, B. Z., \& Xu, Z. F. (2011). Benzyladenine treatment significantly increases the seed yield of the biofuel plant Jatropha curcas. Journal of Plant Growth Regulation, 30(2), 166-174. https://doi.org/10.1007/s00344010-9179-3

R Core Team. (2018). R: A language and environmental for statistical computing. Vienna, Austria. Retrieved from http://www.R-project.org

Raulf, M. (2014). The latex story. Chemical Immunol Allergy, 100, 248-55. https://doi.org/10.1159/000358863 
Rao, G. R., Korwar, G. R., Shanker, A. K., \& Ramakrishna, Y. S. (2008). Genetic associations, variability and diversity in seed characters, growth, reproductive phenology and yield in Jatropha curcas L. accessions. Trees, 22(5), 697-709. https://doi.org/10.1007/s00468-008-0229-4

Schrag, D. P. (2018). The timescales of climate change. Revista (Cambridge), 18(3), 02-82.

Seesangboon, A., Gruneck, L., Pokawattana, T., Eungwanichayapant, P. D., Tovaranonte, J., \& Popluechai, S. (2018). Transcriptome analysis of Jatropha curcas L. flower buds responded to the paclobutrazol treatment. Plant Physiology and Biochemistry, 127, 276-286. https://doi.org/10.1016/j.plaphy.2018.03.035

Sokal, R. R., \& Rolf, F. J. (1995). Biometry: The Principles and Practice of Statistics in Biological Research (3rd ed.). W.H. Freeman and Co., New York.

Wellburn, A. R. (1994). The spectral determination of chlorophylls a and b, as well as total carotenoids, using various solvents with spectrophotometers of different resolution. Journal of Plant Physiology, 144(3), 307-313. https://doi.org/10.1016/S0176-1617(11)81192-2

\section{Copyrights}

Copyright for this article is retained by the author(s), with first publication rights granted to the journal.

This is an open-access article distributed under the terms and conditions of the Creative Commons Attribution license (http://creativecommons.org/licenses/by/4.0/). 